\title{
MARKET PARTICIPATION QUALITY, FIRM COMPETITIVENESS, BUSINESS SUCCESSES AND CORPORATE SUSTAINABILITY: AN EMPIRICAL INVESTIGATION OF ISO 14000 BUSINESSES IN THAILAND
}

\author{
Srisunan Prasertsang, Roi-Et Rajabhat University, Thailand
}

dx.doi.org/10.18374/EJM-13-2.7

\begin{abstract}
This study examines the impacts of market participation quality on corporate sustainability through mediating influences of firm competitiveness and business success. Furthermore, three factors as antecedents, namely, executive long-term vision, environmental change awareness, and growth needs via moderating effects on competitive turbulence. In this study, 108 ISO 14000 businesses in Thailand were chosen as the sample of the study. The results show that market participation quality has a significant effect on firm competiveness and business success. In addition, firm competiveness has a potential positive impact on business success and corporate sustainability. Moreover, business success has positive influence on corporate sustainability. Likewise, the antecedent variables, namely, executive long-term vision, environmental change awareness, and growth needs have positive significant on market participation quality. However, there are no moderating effects in this model. Furthermore, a potential discussion on the results is implemented in the study. Theoretical and managerial contributions are explicitly provided. Conclusion and suggestions, as well as directions of the future research are highlighted.
\end{abstract}

Keywords: Market Participation Quality, Firm Competitiveness, Business Success, Corporate Sustainability, Competitive turbulence 